CAKRAWALA - Repositori IMWI | Volume 3, Nomor 2, Oktober 2020

p-ISSN: 2620-8490; e-ISSN: 2620-8814

\title{
PENGARUH MOTIVATION DAN EMPLOYEE PERFORMANCE TERHADAP PUBLIC SERVICE DI KECAMATAN CISAAT KABUPATEN SUKABUMI
}

\author{
Ryan Kurniawan \\ Program Studi Manajemen, Universitas Widyatama \\ ryan.kurniawan@widyatama.ac.id \\ Muhammad Rezzy Rizaldhi \\ Program Studi Manajemen, Institut Manajemen Wiyata Indonesia \\ rezzy.rizaldi@gmail.com
}

\begin{abstract}
This study aims to determine: (1) the relationship and influence of motivation on public service, (2) the relationship and influence of employee performance on public service, and (3) the relationship and influence of motivation and employee performance simultaneously on public service. The subjects of this research are all employees of Cisaat District, Sukabumi District, totaling 31 people. Methods of data collection through survey by using questionnaire. Data analysis technique used in this research is Multiple Linear Regression Analysis. The results showed that: (1) the motivation positively affect the public service; (2) the employee performance has no effect on public service; (3) simultaneously motivation and employee performance postively affect the public service.
\end{abstract}

Keywords: Motivation, Employee Performance, Public Service.

\section{PENDAHULUAN}

Reformasi birokrasi pada hakekatnya merupakan upaya untuk melakukan pembaharuan dan perubahan mendasar terhadap sistem penyelenggaraan pemerintahan, terutama menyangkut aspekaspek kelembagaan (organisasi) dan sumber daya aparatur. Reformasi tersebut harus dimaknai sebagai penyempurnaan birokrasi yang dinamis secara terus menerus. Kegiatan ini dilakukan dalam rangka meningkatkan kinerja birokrasi, sehingga pelayanan yang diberikan menjadi semakin baik. Reformasi tidak hanya dimaknai sebagai usaha untuk membentuk ulang dan membangun ulang suatu struktur, melainkan sebagai "usaha melaksanakan perbaikan tatanan di dalam struktur" (Devi, 2009).
Pada era otonomi daerah, sistem pemerintahan secara langsung berhadapan dengan masyarakat dan merupakan perwujudan serta perpanjangan tangan pemerintah pusat. Sistem pemerintahan di daerah memiliki peran yang penting di dalam penyelenggaraan urusan-urusan publik. Fungsi dan tugas birokrasi di daerah adalah memberikan pelayanan umum yang bersifat rutin kepada masyarakat, melakukan pemberdayaan terhadap masyarakat untuk mencapai kemajuan dalam kehidupan yang lebih baik, menyelenggarakan pembangunan di tengah masyarakat (Nurhakim Yahya Reza., Ribawanto Heru., 1997).

Pemerintah daerah yang dianggap sebagai penyedia pelayanan bagi masyarakat harus mampu menyelesaikan tanggung jawabnya sebagai aparatur daerah 
dalam memenuhi kebutuhannya. Keberhasilan pemerintah dalam menyelenggarakan pelayanan publik tidak luput dari peranan organisasi pemerintah daerah. Undang-Undang nomor 32 tahun 2004 tentang pemerintahan daerah pada pasal 120 disebutkan bahwa Kecamatan sebagai salah satu perangkat daerah Kabupaten/Kota tertentu yang sangat diharapkan untuk memberikan kontribusinya terhadap pemerintah daerah dalam penyelenggaraan pelayanan publik. Sebagai perangkat daerah, pemerintah kecamatan bertugas menangani sebagian urusan otonomi daerah yang dilimpahkan oleh Bupati/Walikota (Nurhakim Yahya Reza., Ribawanto Heru., 1997).

Kecamatan merupakan organisasi terdepan dalam memberikan pelayanan publik, karena fungsi utama dalam penyelenggaraan tersebut merupakan sebuah kualitas dalam pelayanan yang mencerminkan dari kualiatas birokrasi pemerintah. Saat ini, visi organisasi publik seharusnya sudah beralih dari yang awalnya hanya memfasilitasi pelayanan dengan baik kepada masyarakat menuju ke pelayanan yang selaras dengan kepentingan dan kebutuhan masyarakat luas. Hal tersebut menunjukan bahwa sebuah organisasi khususnya pemerintahan dituntut untuk inovatif dan kreatif dalam menjalankan aturan sesuai yang dibutuhkan oleh masyarakat. Maka dari itu, organisasi pemerintahan tidak hanya bekerja sesuai dengan arahan atau perintah dari atasan saja, melainkan organisasi publik diharapkan dapat lebih peka dalam menghadapi berbagai perubahan yang ada. Faktor yang mempengaruhi pelaksanaan otonomi daerah pada tingkat kota/kabupaten, yaitu keuangan harus cukup dan baik, peralatan harus cukup dan baik, organisasi dan manajemen harus baik, manusia pelaksananya harus baik.

Pelayanan publik bisa terselenggara dengan baik jika diiringi dengan pemberian motivasi terhadap "man" nya. Motivasi bisa dikatakan sebagai faktor pendorong yang berasal dari dalam diri manusia yang akan mempengaruhi cara berfikir dan tindakan seseorang. Dengan demikian, motivasi kerja akan sangat berpengaruh terhadap pekerjaan yang di jalani seorang aparatur. Berbicara masalah motivasi kerja, sangat erat hubungannya dengan performansi pekerjaan. Karyawan akan termotivasi apabila kebutuhannya terpenuhi, dengan terpenuhinya kebutuhan tersebut maka akan timbul kepuasan kerja yang akan berdampak positif pada kinerja aparatur kecamatan (Nurhakim Yahya Reza., Ribawanto Heru., 1997).

Suatu organisasi harus memiliki perencanaan kinerja yang merupakan suatu proses di mana pegawai dan pimpinan bekerjasama merencanakan apa yang harus dikerjakan pegawai, menentukan bagaimana kinerja harus diukur, mengenali dan merencanakan cara mengatasi kendala, serta mencapai pemahaman bersama tentang pekerjaan itu. Kinerja seorang pegawai akan baik bila dia mempunyai keahlian (skill), bersedia bekerja karena diberi gaji, mempunyai harapan (expectation) masa depan lebih baik. Mengenai gaji/upah dan adanya harapan (expectation) merupakan hal yang menciptakan motivasi kerja seorang pegawai bersedia melaksanakan kegiatan kerja dengan kinerja yang baik.

Berikut adalah data kinerja aparatur kecamatan yang ditunjukan dengan rekapitulasi kehadiran pegawai kantor Kecamatan Cisaat tahun 2017 (Rekapitulasi 
Kehadiran Pegawai Kantor Kecamatan Cisaat Tahun 2017, n.d.):

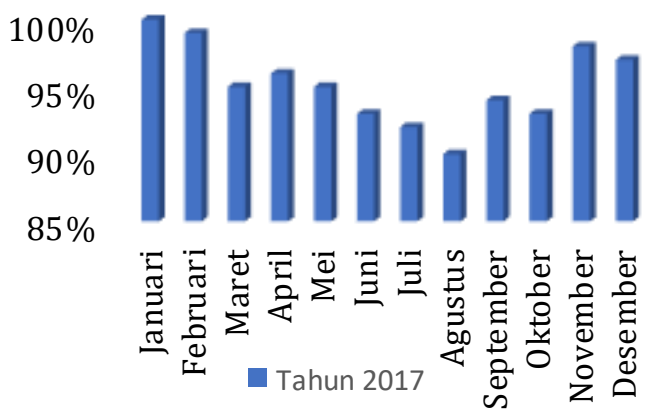

\section{Gambar 1}

Gambar Rekapitulasi Kehadiran Pegawai Kantor Kecamatan Cisaat Tahun 2017

Sumber: Kecamatan Cisaat, Rekapitulasi

Kehadiran Pegawai Kantor Kecamatan Cisaat Tahun 2017

Grafik di atas dapat disimpulkan bahwa tingkat kehadiran 1 tahun terakhir di tahun 2017 hanya di bulan Januari yang mencapai titik maksimal sebesar $100 \%$, selebihnya untuk 11 bulan ke depan masih dibawah angka 100\%. Dapat disimpulkan bahwa pencapaian kerja aparatur belum terlihat maksimal dikarenakan daftar kehadiran aparatur tidak mencapai titik maksimal.

\section{TINJAUAN PUSTAKA}

\section{Teori Manajemen}

Manajemen dapat didefinisikan sebagai proses atau serangkaian kegiatan yang mencakup fungsi manajemen yang dilakukan dengan memanfaatkan sumber daya organisasi yang dimiliki oleh perusahaan untuk mencapai tujuan secara efektif dan efisien. Manajemen adalah suatu kegiatan yang dilakukan untuk mengkoordinasi dan mengawasi kegiatan kerja dari para karyawan sehingga kegiatan kerjanya bisa selesai secara efektif dan efisien sehingga bisa memudahkan perusahaan untuk mencapai tujuannya. Halord Koontz dan Cyril O'Donnel menyatakan bahwa manajemen merupakan suatu usaha yang dilakukan untuk mencapai suatu tujuan oleh orang lain melalui fungsi planning, organizing, staffing, directing, dan controlling(Robbins, 2012).

\section{Teori Manajemen Sumber Daya Manusia (MSDM)}

Suatu proses yang dilakukan oleh setiap organisasi untuk mendapatkan tenaga kerja, melatih tenaga kerja, menilai tenaga kerja, mengompensasi tenaga kerja, untuk mengurus hubungan, kesehatan, dan keselamatan tenaga kerja, serta memberikan haknya atas segala hal yang bersangkutan dengan keadilan adalah definisi manajemen sumber daya manusia menurut Dessler, sedangkan menurut Malayu S.P. Hasibuan manajemen sumber daya manusia (MSDM) ilmu dan seni mengatur hubungan dan peranan tenaga kerja dalam membantu perusahaan untuk mencapai tujuannya dan mengatur penggunaan sumber daya manusia secara efektif dan efisien (Hasibuan, 2013).

\section{Motivation}

Motivation terbentuk dari sikap (attitude) karyawan dalam menghadapi situasi kerja di perusahaan (situation). Motivasi merupakan kondisi atau energi yang menggerakkan diri karyawan yang terarah atau tertuju untuk mencapai tujuan organisasi perusahaan. Sikap mental karyawan yang pro dan positif terhadap situasi kerja itulah yang memperkuat motivasi kerjanya untuk mencapai kinerja maksimal (Robbins, 2012). 
Sikap mental karyawan haruslah memiliki sikap mental yang siap sedia secara psikofisik (siap secara mental, fisik, situasi dan tujuan). Artinya karyawan dalam bekerja secara mental siap, fisik sehat, memahami situasi dan kondisi serta berusaha keras mencapai target kerja.

\section{Indikator Motivation}

Syahyuti mengemukakan bahwa indikator-indikator untuk mengukur motivation (Rita, 2014), yaitu:

1) Dorongan mencapai tujuan

Seseorang yang mempunyai motivasi kerja yang tinggi maka di dalam dirinya mempunyai dorongan yang kuat untuk mencapai kinerja yang maksimal, yang nantinya akan berpengaruh terhadap tujuan dari suatu Lembaga atau instansi.

2) Semangat kerja

Semangat kerja sebagai keadaan psikologis yang baik apabila semangat kerja tersebut menimbulkan rasa senang yang mendorong seseorang untuk bekerja lebih giat dan lebih baik serta konsisten dalam mencapai tujuan yang ditetapkan oleh Lembaga atau instansi.

3) Inisiatif dan kretifitas

Inisiatif diartikan sebagai kemampuan atau kekuatan seseorang aparatur untuk memulai atau meneruskan suatu pekerjaan dengan penuh energi tanpa ada dorongan dari orang lain, sedangkan kreatifitas adalah kemampuan seorang aparatur untuk menemukan hubunganhubungan baru dan membuat kombinasikombinasi yang baru sehingga dapat menemukan ide yang baru.

4) Rasa tanggung jawab

Sikap individu aparatur yang mempunyai motivation kerja yang baik harus mempunyai rasa tanggung jawab terhadap pekerjaan yang mereka lakukan sehingga pekerjaan tersebut mampu diselesaikan secara tepat waktu.

\section{Definisi Employee Performance}

Pada dasarnya kinerja seorang karyawan merupakan hal yang bersifat individual karena setiap karyawan mempunyai tingkat kemampuan yang berbeda dalam mengerjakan tugas pekerjaannya. Kinerja seseorang tergantung pada kombinasi dari kemampuan, usaha dan kesempatan yang diperoleh. Handoko berpendapat bahwa kinerja adalah tingkatan akhir dalam suatu keberhasilan seorang karyawan dalam menyelesaikan pekerjaannya. Kinerja begitu penting untuk mencapai tujuan dan akan mendorong seseorang untuk lebih baik lagi dalam pencapaian tujuan.

Rivai berpendapat bahwa employee performance adalah sikap nyata yang ditunjukkan oleh seorang karyawan sebagai hasil pencapaiannya dalam bekerja yang sesuai dengan fungsi dan kedudukannya dalam perusahaan. Employee Performance instansi merupakan hasil pencapaian dari suatu kegiatan di manajemen suatu instansi di mana pencapaian tersebut merupakan tujuan instansi yang harus dipenuhi oleh semua karyawan. Agar bisa mencapai tujuan tersebut, maka manajemen instansi harus bisa mengatur dan mensiasati bagaimana caranya employee performance instansi bisa tercapai (Sagala, 2013).

\section{Indikator Employee Performance}

Employee Performance pada dasarnya diukur dengan kepentingan organisasi, sehingga indikator dalam pengukurannya disesuaikan dengan kepentingan lembaga itu sendiri. Mondy, Noe, Premeaux dalam (Priansa, 2015) 
menyatakan pengukuran kinerja dapat dilakukan dengan cara sebagai berikut:

1) Kuantitas pekerjaan

Kuantitas pekerjaan berhubungan dengan volume pekerjaan dan produktivitas kerja yang dihasilkan oleh aparatur dalam kurun waktu tertentu atau hasil yang dicapai oleh aparatur dalam jumlah tertentu berdasarkan dengan standar yang telah ditentukan sebelumnya oleh Lembaga.

\section{2) Kualitas pekerjaan}

Kualitas pekerjaan berhubungan dengan standar hasil yang berkaitan dengan mutu yang dihasilkan aparatur. Dalam hal ini merupakan kemampuan aparatur dalam menyelesaikan pekerjaannya sesuai standar berupa kerapihan, ketelitian dan kelengkapan yang telah ditetapkan.

3) Ketepatan waktu

Aparatur dapat menyelesaikan pada waktu yang ditetapkan serta dapat memaksimalkan waktu yang tersedia untuk aktivitas yang lain.

4) Kemandirian

Kemandirian berkaitan dengan kemampuan aparatur untuk berkerja dan mengemban tanggung jawab secara mandiri dengan meminimalisir bantuan orang lain.

5) Inisiatif

Inisiatif dalam menyelesaikan tugas yang artinya aparatur memutuskan atau melakukan suatu pekerjaan dengan benar tanpa harus diberitahu.

6) Kerjasama

Berkaitan dengan kemampuan untuk bekerjasama dengan orang lain.

\section{Definisi Public Service}

Public Service di dalam sistem pemerintahan memiliki sepuluh nprinsip pelayanan umum yang diatur dalam Keputusan Menteri Negara Pemberdayaan Aparatur Negara Nomor
63/KEP/M.PAN/7/2003 tentang pedoman umum penyelenggaraan pelayanan publik, yaitu:
a. Kenyamanan
b. Kedisiplinan
c. Kemudahan akses
d. Prasarana kerja
e. Kelengkapan sarana
f. Tanggung jawab
g. Keamanan
h. Akurasi
i. Kepastian waktu
j. Kesederhanaan

\section{Dimensi Public Service}

Pelayanan publik meliputi lima dimensi yaitu (A. Parasuraman, Valarie A.

Zeithaml, 1985):

1) Tangibles, meliputi fasilitas fisik, perlengkapan dan sarana komunikasi, dalam memberikan pelayanan publik salah satunya dengan menggunakan fasilitas fisik, penampilan aparatur, peralatan dan teknologi. Fasilitas fisik seperti gedung, ruang tempat pelayanan, kebersihan, ruang tunggu, AC, itu semua merupakan salah satu segi dalam kualitas jasa karena akan memberikan kenyamanan bagi masyarakat yang memerlukan pelayanan publik. Penampilan aparatur yang baik akan memberikan rasa dihargai oleh masyarakat yang dilayani, sedangkan dalam peralatan dan teknologi yang digunakan dalam memberikan pelayanan akan memberikan kontribusi pada ketepatan dan kecepatan pelayanan.

2) Reliability, yaitu kemampuan untuk menghasilkan kinerja pelayanan yang dijanjikan secara pasti dan akurat. Hal ini berarti bahwa pelayanan harus tepat waktu dan dalam spesifikasi yang 
sama, tanpa kesalahan, kapanpun pelayanan tersebut diberikan.

3) Responsiveness, yaitu kemampuan para aparatur untuk membantu masyarakat dan memberikan layanan dengan tanggap. Hal ini tercermin pada ketepatan layanan, dan kecepatan.

4) Assurance, yaitu kemampuan, kesopanan, dan sifat dapat dipercaya yang dimiliki oleh para pegawai. Berkaitan dengan kemampuan para pegawai dalam menanamkan kepercayaan kepada masyarakat di dalam memberikan pelayanan publik maka akan menimbulkan keyakinan terhadap Lembaga tersebut.

5) Empathy, yaitu komunikasi yang baik, kemudahan dalam melakukan hubungan dan memahami kebutuhan masyarakat.

\section{Model Analisis dan Hipotesis}

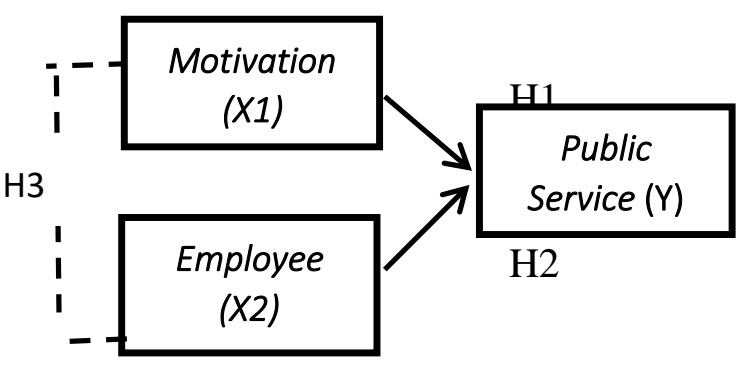

Gambar 2

Model Analisis

Sumber: Hasil Olah Data 2018

Berdasarkan model analisis penelitian, dapat dikemukakan hipotesis penelitian sebagai berikut:

\section{a. Hipotesis Nol $\left(\mathrm{H}_{0}\right)$}

$\mathrm{H}_{0-1}=$ Tidak terdapat pengaruh yang positif dan signifikan Motivation terhadap Public Service Kecamatan Cisaat Kabupaten Sukabumi.

$\mathrm{H}_{0-2}=$ Tidak terdapat pengaruh yang positif dan signifikan Employee
Performance terhadap Public Service Kecamatan Cisaat Kabupaten Sukabumi. $\mathrm{H}_{0-3}=$ Tidak terdapat pengaruh yang positif dan signifikan antara Motivation dan Employee Performance terhadap Public Service Kecamatan Cisaat Kabupaten Sukabumi.

\section{b. Hipotesis Kerja/Alternatif (Ha)}

$\mathrm{Ha}_{-1}=$ Terdapat pengaruh positif dan signifikan Motivation terhadap Public Service Kecamatan Cisaat Kabupaten Sukabumi.

$\mathrm{Ha}_{-2}=$ Terdapat pengaruh positif dan signifikan Employee Performance terhadap Public Service Kecamatan Cisaat Kabupaten Sukabumi.

$\mathrm{Ha}_{-3}=$ Terdapat pengaruh positif dan signifikan antara Motivation dan Employee Performance terhadap Public Service Kecamatan Cisaat Kabupaten Sukabumi.

\section{METODE PENELITIAN}

Jenis penelitian ini menggunakan jenis penelitian kuantitatif untuk mengetahui pengaruh antar variabel. Penelitian ini bertujuan untuk mengetahui pengaruh motivation $(X 1)$ dan employee performance $(X 2)$ terhadap public service (Y). Objek penelitian dalam penelitian ini adalah motivation, employee performance, dan public service. Subjek penelitian adalah pegawai Kecamatan Cisaat Kabupaten Sukabumi.

\section{Populasi dan Sampel Penelitian}

Menurut Sugiyono bahwa "Populasi adalah wilayah generalisasi yang terdiri atas: obyek /subyek yang mempunyai kualitas dan karakteristik tertentu yang ditetapkan oleh peneliti untuk dipelajari dan kemudian ditarik kesimpulannya" (Sugiyono, 2015). Jika peneliti ingin 
menggunakan seluruh elemen yang ada dalam penelitian untuk diteliti, maka penelitian tersebut disebut dengan penelitian populasi. Peneliti menetapkan populasi dalam penelitian ini yaitu semua karyawan Kecamatan Cisaat Kabupaten Sukabumi yang berjumlah 31 orang karyawan.

Menurut Sugiyono bahwa "Sampel adalah bagian dari jumlah dan karakteristik yang dimiliki oleh populasi” (Sugiyono, 2015). Responden yang menjadi sampel untuk menjawab koesioner yang peneliti butuhkan adalah 31 orang karyawan Kecamatan Cisaat Kabupaten Sukabumi.

\section{Operasionalisasi Variabel}

$\mathrm{X} 1$ adalah motivation yang terdiri dari lima dimensi, yaitu physiological needs, safety and security needs, affiliation or acceptance needs, esteem or status needs, actualization.

$\mathrm{X} 2$ adalah employee performance yang terdiri dari lima dimensi, yaitu ketepatan waktu dari hasil, kualitas dari hasil, kuantitas dari hasil, efektivitas, kehadiran.

$\mathrm{Y}$ adalah public service yang terdiri dari lima dimensi, yaitu tangibles, reliability, responsiveness, assurance, empathy.

\section{Pengumpulan Data}

Teknik pengumpulan data adalah dengan angket / kuesioner, (Arikunto, 2013) mengemukakan bahwa angket adalah pernyataan tertulis yang digunakan untuk memperoleh informasi dari responden dalam arti laporan tentang pribadi atau halhal yang Ia ketahui. Demikian pula peneliti akan membuat kuesioner yang akan dibagikan kepada seluruh pegawai Kecamatan Cisaat. Dalam pembuatan kuesioner ini diambil dari teori - teori yang telah disetujui oleh pembimbing.

\section{Analisis data \\ Pengujian Validitas}

Imam Ghozali mengemukakan bahwa uji validitas digunakan untuk mengukur sah atau valid tidaknya suatu kuesioner (Ghozali, 2016). Suatu kuesioner dikatakan valid jika pertanyaan atau pernyataan pada kuesioner mampu untuk mengungkapkan sesuatu yang akan diukur oleh kuesioner tersebut. Pengujian validitas item disini menggunakan korelasi Pearson yaitu dengan cara mengorelasikan skor item dengan skor total item, kemudian pengujian sigifikansi dilakukan dengan kriteria menggunakan $r$ tabel pada tingkat sigifikansi 0,05 dengan uji 2 sisi. Jika nilai positif $r$ hitung $\geq r$ tabel maka dapat dinyatakan valid, dan jika $r$ hitung $\leq r$ tabel maka item dinyatakan tidak valid.

\section{Pengujian Reliabilitas}

Imam Ghozali mendefinisikan uji realibilitas sebagai alat untuk mengukur suatu kuesioner yang merupakan indikator dari variabel atau konstruk (Ghozali, 2016). Suatu kuesioner dikatakan reliabel atau handal jika jawaban seseorang terhadap pernyataan adalah konsisten atau stabil dari waktu ke waktu. Syarat minimum yang dianggap memenuhi syarat adalah jika koefisien alpha cronbach yang dihasilkan lebih besar dari 0,6.

\section{Uji Asumsi Klasik}

Pengujian asumsi klasik bertujuan agar mendapatkan hasil regresi yang bisa di pertanggungjawabkan dan mempunyai hasil yang tidak bias. Dari penelitian ini, asumsiasumsi yang harus dipenuhi adalah tidak terdapat korelasi yang erat antara variabel 
independen (multikolinearitas), tidak terdapat korelasi residual periode $\mathrm{t}$ dengan t-1 (autokorelasi) dan tidak terjadi ketidak samaan varian dari residual satu pengamatan ke pengamatan yang lain (heterokesdastisitas), data yang dihasilkan terdistribusi normal (Ghozali, 2016). Oleh sebab itu, uji asumsi klasik perlu dilakukan, pengujian-pengujian yang dilakukan adalah sebagai berikut:

1. Uji Normalitas

Uji normalitas merupakan salah satu bagian dari persyaratan analisis data dan bertujuan untuk menguji data apakah data yang didapat memiliki distribusi yang normal atau tidak (Ghozali, 2016). Uji Normalitas dapat dilakukan dengan melihat pada grafik distribusi normal (histogram). Data dikatakan normal jika bentuk kurva memiliki kemiringan yang cenderung imbang, baik dari sisi kiri maupun sisi kanan. Dalam bentuk kurva menyerupai lonceng yang hampir sempurna. metode pengujian normalitas bisa dilakukan dengan metode One-Sample Kolmogorov-Smirnov Test, jika (nilai $>\propto=0,05$ ) maka data berdistribusi normal. Jika, (nilai $<\propto=0,05$ ), maka data tidak berdistribusi normal.

\section{Uji Multikoleniaritas}

Uji multikolinearitas menurut Imam Ghozali bertujuan untuk menguji apakah model regresi ditemukan adanya korelasi antar variabel bebas (independen). Priyatno menyebutkan bahwa suatu model regresi bebas dari multikolinearitas jika mempunyai nilai VIF $<10$ dan mempunyai angka tolerance $>0,1$.

\section{Uji Heteroskedastisitas}

Uji heteroskedastisitas menurut Imam Ghozali bertujuan untuk mengetahui apakah di dalam model regresi terjadi ketidaksamaan variance dari suatu residual pengamatan ke pengamatan lain (Ghozali, 2016). Heterokedastisitas menunjukkan penyebaran variabel bebas. Penyebaran yang acak menunjukkan model regresi yang baik, dengan kata lain homokedastisitas atau tidak terjadi heterokedastisitas. Pengujian heteroskedastisitas dapat dilihat dengan menggunakan scatterplot, jika scatterplot menghasilkan titik - titik yang tidak membentuk suatu pola dan menyebar di atas dan di bawah nol pada sumbu Y, maka tidak terjadi heteroskedasitas. Jika scatterplot menghasilkan titik-titik yang membentuk suatu pola dan menyebar di atas dan di bawah nol pada sumbu Y, maka terjadi heteroskedasitas.

\section{Teknik Analisis Data}

Teknik analisis data yang digunakan dalam penelitian ini adalah teknik analisis deskriptif. Teknik analisis deskriptif adalah bagian dari statistika yang digunakan untuk menggambarkan atau mendeskripsikan kumpulan data atau hasil pengamatan yang telah dilakukan (Ghozali, 2016). Alat ukur yang dibuat peneliti adalah berupa kuesioner yang akan diberikan kepada responden, dimana responden memilih alternatif jawaban dengan cara memberikan tanda ceklis $(\sqrt{ })$ pada jawaban yang dipilih. Setiap pertanyaan diberikan skor dari nilai satu sampai lima, dimana skor lima menunjukan nilai positif dan skor satu menunjukan nilai yang negatif, dengan rincian jawaban yang dapat dilihat sebagi berikut:

Tabel 1

Skala Likert

\begin{tabular}{cc}
\hline Pertanyaan & $\begin{array}{c}\text { Untuk Skor } \\
\text { Jawaban }\end{array}$ \\
\hline Sangan Setuju & 5 \\
\hline Setuju & 4 \\
\hline Kurang Setuju & 3 \\
\hline Tidak Setuju & 2 \\
\hline Sangat Tidak Setuju & 1 \\
\hline
\end{tabular}




\section{Uji Asumsi Klasik}

\section{HASIL PENELITIAN DAN PEMBAHASAN}

\section{Uji Validitas}

Hasil uji validitas pada butir-butir pertanyaan ditentukan berdasarkan perbandingan antara $r$ hitung dengan $r$ tabel. Item soal dinyatakan valid ketika diperoleh $r$ hitung $\geq r$ tabel. Diketahui $r$ tabel $=$ untuk jumlah sampel $n=31$ pada $\alpha=0,05$ adalah 0,33 . Maka selanjutnya ditetapkan bahwa butir soal dinyatakan valid jika diperoleh $r$ hitung $\geq 0,33$. Hasil uji validitas menunjukkan bahwa semua variabel memiliki pertanyaan dengan nilai $r$ hitung > r table.

\section{Uji Reliabilitas}

Hasil uji reliabilitas dari 3 variabel, yaitu Motivation, Employee Performance dan Public Service menunjukkan bahwa teknik yang digunakan adalah Cronbach Alpha dan untuk menentukan suatu instrumen reliabel atau tidak maka bisa menggunakan batas nilai Alpha 0,6. Nunnally dalam Imam Ghozali mengatakan bahwa suatu konstruk atau variabel dikatakan reliable jika memberikan nilai Cronbach Alpha > 0,600 (Ghozali, 2016). Nilai Cronbach Alpha dari variabel motivation $\left(\mathrm{X}_{1}\right)$ adalah 0,849 , artinya dapat diterima. Variabel kedua, yaitu employee performance $\left(\mathrm{X}_{2}\right)$ juga menunjukkan nilai Cronbach Alpha 0,817, rtinya dapat diterima. Variabel ketiga yaitu public servie (Y) yang memiliki nilai hitung Cronbach Alpha 0,801 juga bisa diterima. Output yang dihasilkan menunjukkan bahwa semua nilai Cronbach Alpha dari ketiga variabel sudah memasuki kondisi reliabel.

\author{
Hasil-hasil dari pengujian asumsi \\ klasik yang diuji adalah uji normalitas, uji \\ multikolinearitas, uji heteroskedastisitas.
}

\section{Uji Normalitas}

metode pengujian normalitas bisa dilakukan dengan metode One-Sample Kolmogorov-Smirnov Test, jika (nilai $>\propto=0,05)$ maka data berdistribusi normal. Jika, (nilai $<\propto=0,05$ ), maka data tidak berdistribusi normal. Uji normalitas pada penelitian ini dibantu oleh perhitungan SPSS, berikut hasil uji normalitas:

Hasil data tabel di atas menunjukkan bahwa pada kolom kolmogrov-smirnov dapat diketahui nilai signifikansi (Asyump.sig 2 tailed) yaitu sebesar 0,451. Nilai signifikansinya lebih besar dari $0,05(0,451>0,05)$ maka nilai residualnya adalah normal. Jadi, dapat disimpulkan bahwa model regresi pengaruh variabel bebas $\mathrm{X}_{1}$ dan $\mathrm{X}_{2}$ secara bersamasama terhadap variabel terikat $\mathrm{Y}$ telah memenuhi persyaratan normalitas data.

\section{Uji Multikoleniaritas}

Hasil uji multikoleniaritas menunjukan bahwa nilai korelasi antar variabel bebas/independen, yaitu variabel $\mathrm{X}_{1}$ (Motivation) dan variabel $\mathrm{X}_{2}$ (Employee Performance) mempunyai nilai output VIF yang sama yaitu sebesar 1,692 dan nilai output tolerance masing-masing variabel menunjukkan angka yang sama pula yaitu 0,591 . Setiap variabel bebas mempunyai nilai VIF < 10 dan nilai tolerance > 0,1. Jadi dapat disimpulkan bahwa tidak terjadi multikolinieritas antar variabel bebas dalam model regresi ini. 


\section{Uji Heteroskedastisitas}

Bermula dari grafik scatter plot yg telah diolah menunjukkan bahwa diagram pencar yang terbentuk ternyata tidak membentuk suatu pola dan titik-titik menyebar secara acak serta tersebar baik di atas maupun di bawah angka 0 pada sumbu Y. Dengan demikian dapat disimpulkan pada model regresi pengaruh variabel $X_{1}$ dan $\mathrm{X}_{2}$ secara bersama-sama terhadap variabel Y tidak terjadi Heteroskedastisitas.

\section{Uji Hipotesis}

Pengujian hipotesis dilakukan dengan menggunakan analisis regresi linear berganda, dengan memprediksi seberapa besarnya hubungan variabel bebas terhadap variabel terikat. Selain itu dilakukan pula uji t dan uji F. Perhitungan statistik dalam penelitian ini adalah dengan menggunakan bantuan program SPSS, berikut adalah hasil analisis regresi linear berganda dalam penelitian ini.

\section{Uji Analisis Regresi Berganda}

Hasil analisis regresi linear berganda memperoleh model regresi sebagai berikut:

$$
\mathrm{Y}^{*}=15,081+0,947 \mathrm{X}_{1}+0,258 \mathrm{X}_{2}
$$

Interpretasi model regresi tersebut adalah sebagai berikut:

a. $\quad \mathrm{a}=15,081$

Hasil ini menunjukkan bahwa tanpa adanya pengaruh dari variabel variabel bebas terhadap variabel $\mathrm{Y}$ (public service), maka total skor variabel Y sebesar 15,08.

b. $b_{1}=0,947$

Hasil ini menunjukkan bahwa apabila terdapat kenaikan satu skala tanggapan pada variabel X1, maka akan terjadi peningkatan pada total skor variabel $\mathrm{Y}$ sebesar 0,947. Jadi apabila terjadi peningkatan pada variabel X1 maka variabel Y pun akan meningkat.

c. $\mathrm{b}_{2}=0,258$

Hasil ini menunjukkan bahwa apabila terdapat kenaikan satu skala tanggapan pada variabel X2, maka akan terjadi peningkatan pada total skor variabel $\mathrm{Y}$ sebesar 0,258. Jadi apabila terjadi peningkatan pada variabel X2 maka variabel Y pun akan meningkat.

\section{Uji t}

Imam Ghozali mengemukakan bahwa uji $\mathrm{t}$ digunakan untuk menunjukkan seberapa jauh pengaruh satu variabel penjelas/independen secara individual dalam menerangkan variasi variabel dependen. Hasil uji t menunjukan bahwa variabel motivation $\left(\mathrm{X}_{1}\right)$ memiliki nilai $\mathrm{t}$ hitung sebesar 5,810, pada analisis regresi digunakan probabilitas 2 sisi untuk mengetahui nilai $\mathrm{t}$ tabel, distribusi $\mathrm{t}$ dicari pada $a=5 \%: 2=2,5 \%$ (uji 2 sisi) dengan derajat kebebasan (df) n-k atau 31-3 = 28 (n adalah jumlah kurun waktu pada observasi dan $\mathrm{k}$ adalah jumlah variabel), dengan pengujian 2 sisi (signifikansi $=0,025$ ) maka diperoleh hasil untuk t tabel yaitu sebesar 2,04841. Nilai t hitung variabel motivation lebih besar dari nilai $\mathrm{t}$ tabel $(5,810>$ 2,04841) dengan tingkat signifikan di bawah 0,05 yaitu sebesar 0,000 $(0,000<$ 0,05) maka Ho ditolak dan Ha diterima. Nilai $t$ hitung variabel employee performance $\left(\mathrm{X}_{2}\right)$ lebih kecil dari pada nilai $\mathrm{t}$ tabel $(1,406<2,04841)$ dengan tingkat signifikan di atas 0,05 yaitu $0,171(0,171>$ 0,05), maka Ho diterima dan Ha ditolak.

\section{Uji F}

Berdasarkan perhitungan melalui SPSS didapatkan hasil $\mathrm{F}$ hitung variabel $\mathrm{X}_{1}$ 
(Motivation), $\mathrm{X}_{2}$ (Employee Performance), dan Y (Public Service) di Kecamatan Cisaat Kabupaten Sukabumi sebesar 39,074. Selanjutnya nilai $F$ hitung tersebut dibandingkan dengan nilai $\mathrm{F}$ tabel (lihat pada lampiran) dengan didasarkan pada $\mathrm{dk}$ pembilang $=2$ dan $\mathrm{dk}$ penyebut $=31-2-1=$ 28. Adapun taraf kesalahan yang diterapkan adalah 5\%, sehingga diperoleh nilai $\mathrm{F}$ tabel adalah 3,34. Kriteria Pengujian Hipotesisnya yaitu:

Jika $F_{\text {hitung }} \geq F_{\text {tabel }}$ maka signifikan

Jika $F_{\text {hitung }}<\mathrm{F}_{\text {tabel }}$ maka tidak signifikan

Hasil nya adalah $39,074 \geq 3,34$, artinya terdapat pengaruh siginifikan antara Motivation $\left(\mathrm{X}_{1}\right)$ dan Employee Performance $\left(\mathrm{X}_{2}\right)$ terhadap Public Service (Y) pada Kecamatan Cisaat Kabupaten Sukabumi. Berdasarkan hasil perhitungan bahwa $F_{\text {hitung }}$ $\geq \mathrm{F}_{\text {tabel }}$ maka $\mathrm{H}_{1}$ diterima, dengan kata lain titik kritis 3,34 untuk $n=31$ diperoleh dari pengaruh ketiga variabel yaitu Motivation dan Employee Performance sebagai variabel bebas terhadap Public Service sebagai variabel terikatnya sebesar 39,074 maka dari ketiga variabel tersebut terdapat pengaruh positif dan signifikan.

\section{Pembahasan}

Penelitian mengenai pengaruh motivation dan employee performance terhadap public service pada Kecamatan Cisaat Kabupaten Sukabumi, dapat dibuat pembahasan sebagai berikut:

\section{Pengaruh Motivation terhadap Public Service}

Penelitian yang dilakukan oleh peneliti menunjukkan hasil bahwa Motivation yang diberikan oleh pihak atasan kepada karyawan Kecamatan Cisaat Kabupaten Sukabumi berpengaruh positif dan signifikan. Hubungan antara Motivation dengan Public Service diperkuat dari hasil analisis regresi penelitian ini. Hal ini dibuktikan dengan nilai signifikasi untuk variabel motivation sebesar $0,000<0,05$ menunjukkan bahwa variabel Motivation berpengaruh signifikan terhadap Public Service.

\section{Pengaruh Employee Performance terhadap Public Service}

Penelitian yang dilakukan oleh peneliti menunjukkan hasil bahwa karyawan yang memiliki Employee Performance yang tinggi akan bekerja dengan baik dan optimal. Hubungan antara Motivation dengan Public Service diperkuat dari hasil analisis regresi penelitian ini. Hal ini dibuktikan dengan nilai signifikasi untuk variabel employee performance sebesar 0,171>0,05 menunjukkan tidak adanya pengaruh Employee Performance terhadap Public Service.

\section{Pengaruh Motivation dan Employee Performance terhadap Public Service}

Hasil penelitian yang telah dijelaskan di atas dapat disimpulkan bahwa Motivation dan Employee Performance secara simultan mampu memengaruhi Public Service. Hasil uji F sebesar 39,074 menunjukkan bahwa kedua variabel independen secara simultan berpengaruh terhadap Public Service.

\section{SIMPULAN DAN SARAN}

\section{Simpulan}

Simpulan tentang penelitian pengaruh compensation dan motivation terhadap employee performance pada CV Sumber Milik Farm Sukabumi adalah sebagai berikut:

1. Hasil penelitian uji $\mathrm{t}$ menunjukkan bahwa variabel Motivation $\left(\mathrm{X}_{1}\right)$ secara parsial berpengaruh secara signifikan terhadap variabel Y (Public service). 
Hal tersebut ditunjukkan dari hasil uji $\mathrm{t}$ hitung $\geq \mathrm{t}$ tabel yaitu sebesar $5,810 \geq$ 2,04841 dengan tingkat signifikansi di bawah 0,05 yaitu 0,000. Hal ini menunjukkan bahwa Motivation memberikan pengaruh positif dan signifikan terhadap Public Service.

2. Hasil penelitian uji $\mathrm{t}$ menunjukkan bahwa Variabel Employee Performance $\left(\mathrm{X}_{2}\right)$ secara parsial tidak berpengaruh secara signifikan terhadap variabel $\mathrm{Y}$ (Public service). Hal tersebut ditunjukkan dari hasil uji $\mathrm{t}$ hitung $<\mathrm{t}$ tabel yaitu sebesar $1,406<2,04841$ dengan tingkat signifikansi di atas 0,05 yaitu 0,171. Hal ini menunjukkan bahwa Employee Performance tidak berpengaruh secara signifikan terhadap variabel Y (Public service).

3. Hasil penelitian uji $\mathrm{F}$ menunjukkan bahwa variabel $\mathrm{X}_{1}$ (Motivation), $\mathrm{X}_{2}$ (Employee Performance), berpengaruh dan signifkan terhadap Y (Public Service) di Kecamatan Cisaat Kabupaten Sukabumi. Hal tersebut dibuktikan dari hasil $F_{\text {hitung }} \geq F_{\text {tabel }}$ yaitu sebesar 39,074 $\geq 3,34$ dengan tingkat signifikansi di bawah 0,05 yaitu 0,000.

\section{Saran}

Penelitian yang dilakukan oleh peneliti menunjukkan hasil berupa beberapa saran yang bisa diberikan kepada Kantor Kecamatan Cisaat Kabupaten Sukabumi untuk meningkatkan Public Service Kecamatan Cisaat Kabupaten Sukabumi. Saran-saran tersebut antara lain:

1. Penelitian yang dilakukan oleh peneliti menunjukkan hasil bahwa variabel Motivation berpengaruh terhadap Public Service di Kecamatan Cisaat Kabupaten Sukabumi. Jadi, apabila instansi ingin lebih meningkatkan
Public Service-nya, maka sebaiknya instansi Kecamatan bisa lebih fokus untuk meningkatkan Motivation karyawan agar Public Service-nya terus meningkat.

2. Penelitian yang dilakukan oleh peneliti menunjukkan hasil bahwa variabel Employee Performance berpengaruh negatif terhadap Public Service di Kecamatan Cisaat Kabupaten Sukabumi. Karena semakin tinggi Employee Performance maka semakin tinggi pula Public Servicenya.

3. Penelitian yang dilakukan oleh peneliti menunjukkan hasil bahwa variabel Motivation dan Employee Performance berpengaruh positif dan signifikan terhadap Public Service di Kecamatan Cisaat Kabupaten Sukabumi. Agar Public Service nya meningkat, diperlukan Motivation dan Employee Performance yang tinggi.

\section{DAFTAR PUSTAKA}

A. Parasuraman, Valarie A. Zeithaml, L. L. B. (1985). A Conceptual Model of Service Quality and Its Implications for Future Research. Journal of Marketing.

Arikunto, S. (2013). Prosedur Penelitian Suatu Pendekatan Praktik. Rineka Cipta.

Devi, E. K. D. (2009). Analisis Pengaruh Kepuasan Kerja Dan Motivasi Terhadap Kinerja Karyawan Dengan Komitmen Organisasional Sebagai Variabel Intervening ( Studi Pada Karyawan Outsourcing Pt Semeru Karya Buana Semarang ).

Ghozali, I. (2016). Aplikasi Analisis Multivariate dengan Program IBM SPSS 23. Badan Penerbit Universitas 
Diponegoro.

Hasibuan, M. S. . (2013). Manajemen Sumber Daya Manusia, cetakan ke-21. Bumi Aksara.

Nurhakim Yahya Reza., Ribawanto Heru., H. M. (1997). elayanan Publik di Kecamatan Giri Kabupaten Banyuwangi. Jurnal Administrasi Publik.

Priansa, D. J. (2015). Pengaruh Kepemimpinan Visioner Dan Etos Kerja Terhadap Kinerja Pegawai Bank Syariah Mandiri. Ecodemikca.
Rekapitulasi Kehadiran Pegawai Kantor Kecamatan Cisaat Tahun 2017.

Rita, P. (2014). Pengaruh Motivasi Kerja dan Pelatihan Kerja Terhadap Kinerja Karyawan pada Kantor Pelayanan Pajak Pratama Magelang.

Robbins, P. S. T. A. J. (2012). Perilaku Organisasi. Salemba Empat.

Sagala, R. (2013). Manajemen Sumber Daya Manusia untuk Perusahaan. Rajawali Pers.

Sugiyono. (2015). Metode Penelitian Kuantitatif, Kualitatif dan $R \& D$. Alfabeta. 